ESSAY ROUNDTABLE

\title{
PROTESTANT LEGAL THEORY? APOLOGY AND OBJECTIONS
}

\author{
JEFFREY B. HAMMOND \\ Associate Professor of Law, Faulkner University, Thomas Goode Jones School of Law
}

KEYWORDS: Legal theory, Protestant legal theory, jurisprudence

\section{INTRODUCTION}

The academic interdisciplinary study of law and religion is in a unique place, brimming with hope and promise. This constellation of scholars, conferences, journals, academic centers, books and book series, and public interest law firms has matured considerably since the "path-breaking" commencement of the movement, the publication of Harold Berman's I974 short book, The Interaction of Law and Religion. ${ }^{\mathrm{I}}$ No longer can the study of law and religion be solely identified with the study of the First Amendment's religion clauses. Scholars have explored topics both large scale and fine grain in history, church law, the intersection of religious ethics and law, religion and international human rights law, and in other subareas of the field. ${ }^{2}$

Now is the unique time for the legal and theological academies at large to fully embrace religion's place within the warp and weft of the law. To be sure, this fulsome integration has happened in both Islamic and Jewish Law, with both disciplines birthing full-scale jurisprudences, or theories of law, on the grand, fundamental questions of law (What is law? Why must law be obeyed?) and questions of how Islamic and Jewish theology apply to many different divisions and subject matters of the law, such as family law and matters of inheritance and succession. ${ }^{3}$ Further, Roman Catholic scholars have integrated Catholic social teaching, magisterial documents, and other church pronouncements to fashion Catholic legal theory. There is, in fact, a well-known blog featuring the efforts of astute and accomplished scholars, whose aim it is to craft a Catholic legal theory. ${ }^{4}$

I Harold J. Berman, The Interaction of Law and Religion (Nashville: Abingdon Press, 1974). For the description of The Interaction of Law and Religion as "path-breaking," see John Witte, Jr. and Christopher J. Manzer, introduction to Harold J. Berman, Law and Language: Effective Symbols of Community, ed. John Witte, Jr. (Cambridge: Cambridge University Press, 20I3).

2 David Skeel offers his own four-part typology of "Christian legal scholarship" in David A. Skeel, Jr., "The Unbearable Lightness of Christian Legal Scholarship,” Emory Law Journal 57, no. 6 (2008): I47I-I 525.

3 See, for example, Michael J. Broyde, The Pursuit of Justice and Jewish Law: Halakhic Perspectives on the Legal Profession (New York: Yashar Books, 2007); see also, Abdullah A. An-Na'im, Islamic Family Law in a Changing World: A Global Resource Book (London: Zed Books, 2002).

4 See Mirror of Justice, www.mirrorofjustice.blogs.com, which self-referentially calls itself "a blog dedicated to the development of Catholic legal theory"; but see John Finnis, Natural Law and Natural Rights (Oxford: Oxford University Press, 1980) (for an example of Catholic legal theory that is a synthesis of Thomist and Aristotelian philosophies). 
There is not (at least as this author can tell) a current, concentrated effort to fashion a discernibly Protestant legal theory - a unified theory of law that has as its foundation Protestant theology. To be sure, over the past several years, Protestant scholars have grappled with many questions that can be included in the broad umbrella of Protestant legal theory. ${ }^{5}$ These Protestant scholars and theorists have labored in what I call the "second leg" of Protestant legal theory, in which they react to large scale issues in one or more areas of the law, or they react to other theories of law with a particular Christian idiom. ${ }^{6}$ However, to date, apart from the continental philosopher Herman Dooyeweerd, the Dutch Calvinist whose writings are almost impenetrable in their complexity, there has yet to be a Protestant legal theorist who has attacked the large-scale questions of jurisprudence as a whole, constructively, critically, and comprehensively, self-referentially and selfconsciously as a Protestant. 7 Such a unified, large-scale jurisprudence or legal theory is what I call the "first leg" of a Protestant legal theory. ${ }^{8}$

Protestant legal theory exists as a reason, in and of itself, to understand the law. It seeks to unify two bodies of knowledge: theology, the knowledge of study of God, and jurisprudence, the knowledge and study of law. It is a self-conscious advancement of the scholarship that has preceded it in the field of law and religion, and it seeks to carve a space alongside the work done by historians, human rights scholars, First Amendment professors, and public interest lawyers to make a theoretical mooring upon which new practical work may be done.

An argument for Protestant theology's seat at legal theory's table is grounded on one main claim: religion is special. Religion motivates and directs human action. It identifies matters of primary importance in its adherents' lives. It calls its followers to give fealty and homage to goods and goals greater than the worshipper himself. Correlatively, because it occupies such a large space within religion in general, Protestantism and Protestant theology is special. Protestant theology, in one form or another, has directed the religious thoughts and practices of hundreds of millions of hearts and souls for over five hundred years.

However, the proposition that was once unassailable is now very much in doubt. Law and religion scholars and other law professors have recently launched fusillades against the proposition that religion is unique or special or should otherwise play any significant role in understanding common duties or rights. 9 This essay, therefore, merely announces that there is an option for a

5 Of the many books and articles, see, for example, David VanDrunen, Divine Covenants and Moral Order: A Biblical Theology of Natural Law (Grand Rapids: William B. Eerdmans, 20r4); Robert F. Cochran, Jr. and David VanDrunen, eds., Law and the Bible: Justice, Mercy and Legal Institutions (Downers Grove: InterVarsity Press, 2013) (containing Protestant and other Christian perspectives); Michael W. McConnell, Robert F. Cochran, Jr., and Angela C. Carmella, eds., Christian Perspectives on Legal Thought (New Haven: Yale University Press, 200I) (containing Protestant and other Christian perspectives).

6 For an article that responds to a theory of law, positivism, in a compelling Christian voice, see Frank S. Alexander, "Beyond Positivism: A Theological Approach," in "The Constitution and Human Values: The Unfinished Agenda," special issue, Georgia Law Review 20, no. 4 (1986): 1089-135.

7 For one of Dooyeweerd's many writings on the nature of law, see Herman Dooyeweerd, Encyclopedia of the Science of Law, Collected Works, series A, volume 8, book I (Grand Rapids: Paideia Press, 20I 2).

8 In addition to their other exceptional work in law and religion, Harold Berman and John Witte have cracked the door open regarding the bases upon which a Christian jurisprudence may be built. See Harold J. Berman, "Toward an Integrative Jurisprudence: Politics, Morality, History," California Law Review 76, no. 4 (I988): 779-80I; John Witte, Jr., "Law and Religion: The Challenges of Christian Jurisprudence," in "Can the Seamless Garment Be Sewn? The Future of Pro-Life Progressivism," special issue, University of St. Thomas Law Journal 2, no. 2 (2005): 439-52.

9 See, for example, Micah Schwartzman, "What If Religion Is Not Special?," University of Chicago Law Review 79, no. 4 (2OI2): I35I-427; Brian Leiter, Why Tolerate Religion? (Princeton: Princeton University Press, 20I3). 
bridge to span the chasm of skepticism opened by this recent spate of scholarship by asserting Protestant theology's place at legal theory's table. However, any substantive Protestant, Catholic, Islamic, Jewish, Buddhist, or other legal theory, will rise or fall on its own merit and its own ability to persuade those who have "ears to hear" and "eyes to see" that which is being theorized and construed.

In this brief essay, I make an apology for such a Protestant jurisprudence. In what follows, I first argue for what legal theory is, what Protestant legal theory is, and of what it might consist. I also raise what might be the most common objections to the very thought of a Protestant legal theory and what I believe to be reasonable responses to those objections.

\section{WHAT IS LEGAL THEORY? AND WHAT IS PROTESTANT LEGAL THEORY?}

\section{What Is Legal Theory?}

Legal theory, or jurisprudence, seeks to holistically understand law as a body of knowledge. ${ }^{\text {Io }}$ Legal theory asks basic, yet perennial, questions about law such as: what is law? Why does law exist in a society instead of brute force? Who creates law, and why do those persons or people have the prerogative to do so? Why obey law, and what are the consequences if law is not followed? What role, if any, does justice serve in the making, obedience to, and execution of law?

In addition to fundamental questions that can be asked of law in general, similar general questions can be asked of particular areas of the law. For example, some of the foundational questions that constitutional theorists have asked are these: Why charter a political grouping of people around a constitution instead of the will of a dictator? In what way(s) should power be divided between the institutions of a government that a constitution establishes? Are rights granted by the constitution or are they merely recognized, inhering instead in nature, God, or some other prepolitical being or force? Is a constitution a static document, or does it evolve over time according to the needs, beliefs, and mores of the society that it governs?

Legal theory's usefulness is found in its ability to ask and answer questions that are not so specific that they would be unrecognizable to a general theorist of law, yet those questions not so broad as to be foreign to one who is a tort, or contract, or property, or criminal law, or constitutional theorist. In sum, legal theory occupies the middle space of "both/and" and not "either/or." Previously, I called the more general scholarship the "first leg" of legal theory, while the more situated, discipline-specific questions might be called the "second leg" of legal theory. Legal theory

Io There has been not a small amount of controversy about the differences, if any, between the terms legal theory, jurisprudence, and philosophy of law. Georgetown law professor Lawrence Solum helpfully distinguishes between the terms in an article on his blog. See Lawrence Solum, "Legal Theory Lexicon 044: Legal Theory, Jurisprudence, and the Philosophy of Law," Legal Theory Lexicon (blog), May 30, 2005, http://lsolum.typepad.com/legal_theory_ lexicon/2005/05/legal_theory_le.html. Consider what Solum has to say about the term legal theory:

Legal theory is a much broader and encompassing term, encompassing the philosophy of law and jurisprudence as well as theorizing from a variety of other perspectives, including law and economics and the law and society movement. In my opinion, "legal theory" is currently the best neutral term for referring to legal theorizing, broadly understood. It allows us to avoid the turf wars and sectarian disputes that make the word "jurisprudence" somewhat problematic.

Ibid. Therefore, in this essay I adopt legal theory as a synonym of jurisprudence. 
can ask the most basic questions of law as a sociological enterprise, and it can also pluck, prod, and goad those who have wondered why particular areas of the law exist in the first place.

Protestant legal theory is therefore the active, searching, humble, theologically oriented, biblically focused theorizing about the nature, purposes, functions, orientations, and consequences of law as a discipline (the first leg of legal theory). Protestant legal theory is also engaged in the quest for theoretical answers to theological questions that arise as law manifests itself in many forms as the law interacts with human choices and action of all kinds (the second leg). ${ }^{\text {II }}$

\section{Why Legal Theory Instead of Legal Theology?}

Legal theory exists as a discipline within the law for a few reasons. Because the law impinges upon every living person's actions, rights, duties, and aspirations every day (even without one consciously reflecting on such an impingement), it is appropriate to ask the deep questions of law, to help one understand law's place and purpose in governing human lives and relationships. Further, the law is a capacious, deep well and can handle multiple theoretical perspectives about it. Just as there are feminist, critical, and other "perspectival" theologies, there are manifold feminist, critical, sociological, economic, and other legal theories. Each one brings unique and valuable "glasses" to reading the law. Also, every knowledge-based discipline seeks to understand itself at the same time its practitioners are executing the discipline. Think of, for example, how the same university's college of natural sciences can have philosophers of science who seek to understand what is most basic about science and biologists, chemists, and physicists working in it, while the college trains the next generation of biologists, chemists, and physicists. The same is true with legal theory: the same university can employ general legal theorists who seek to understand what is most basic about the law and labor lawyers who theorize about the perennial questions of labor law, contract theorists who muse about the ultimate standards of contract law, and the like, and at the same time train the new wave of labor and transactional lawyers.

But the question remains: Why legal theory instead of legal theology? The answer, I believe, rests with the foundation upon which the theorizing lies. Ultimately, the point of legal theory, much less Protestant legal theory, is to make a point (or points) about law as its own enterprise. Protestant theology is a tool that aids the theorist in making that point or points; yet, the final claim is about the nature, properties, or functions of law. The theorist might claim that a fine point of theology impinges upon, interprets, or explains a proposition or conundrum in the law. But, in the end, the interpreted or explained point is about the law, and theology is the vehicle through which the point is made. If, instead, the theorizing were called "legal theology," it seems that the emphasis is exactly the opposite. The theorist would be exploring and excavating the legal implications found in theology, if any are to be found. At first blush, this seems to be a much harder project.

Nevertheless, a "theology of law," in which law being theorized about through the vehicle of theology, is rife with possibilities. It does not necessarily have to be historically focused (though it can deploy great theological interactions with law in the history of Protestantism). Rather, it can be in part or in whole a constructive theology. If in whole, the constructive theology of law could deploy the traditional "loci" of systematic theology-the doctrines of theology proper, Christology, soteriology, ecclesiology, pneumatology, and so on-in a comprehensive way to

I I For more on the role of intellectual humility in crafting a Christian interaction with law, see Ellen Ott Marshall, "Theological Humility in the World of Law," Journal of Law and Religion 32, no. I (2017) (this issue). 
build a theory of law on the fundamental questions of law (such as what is law, and why do humans in society obey law). ${ }^{\mathrm{I2}}$ As examples, from this author's perspective, any constructive theology of law must address the following questions: What role does the God who demands holiness of those follow God play in the fashioning, making, and adherence to human laws and legal institutions? In what ways does human law mold flawed human beings who bear the image of God, yet who are radically marred by the effects of Adam's fall? Similarly, because human law exists in a fallen world and is executed by flawed and fallen human beings, what role does sin play in the making and working out of the law? There are, of course, many other large-scale questions that this first leg of Protestant legal theory could address.

The other possibility for a constructive theology of law is to focus on one or more discreet areas of theology as the interpretive grid placed on top of one or more discreet areas of the law (the second leg of Protestant legal theory). For example, a constructive theorist could use theological anthropologies coupled with theological insights into creation and redemption to critique basic questions in American health law and policy. Or as another example, it would be very interesting to read a critique of the "efficient breach" theory in contemporary contract doctrine, which says that a party to a contract can freely and without compunction of conscience breach his contract, as long as he pays damages, alongside an exposition of the God of the Old Testament as a promisemaking and promise-keeping deity, concluding with the implications of such a promise-making God for contemporary Christians who enter the marketplace.

\section{POSSIBLE OBJECTIONS TO PROTESTANT LEGAL THEORY}

\section{Authority}

There are several potential objections to the making of a Protestant legal theory. Initially, a critic of the project could ask why the focus is on fashioning a Protestant legal theory instead of a Christian legal theory. Two answers immediately come to mind. One regards the fundamental issue of authority. There are, of course, many points of consonance between Protestant legal theorists and Catholic legal theorists who depend on Roman Catholic social teaching and other magisterial pronouncements as the basis for their theorizing. The question of authority likely remains a wide and unbridgeable gap. The Protestant legal theorist would likely begin his theorizing with the Bible. While the Catholic theorist would inevitably pivot, at some point in constructing the theory, to the church's conclusive pronouncements on the matter. The Protestant's criticism is that the Catholic does not rest on the authority that is most important-the Bible-while the Catholic's criticism is that the Protestant cannot find true authority for any pronouncement about the world because the Protestant's reading of the Bible is idiosyncratic, even private.

It is ambitious enough for a Protestant theorist to construct a theory that speaks from his particular confessional background. It would be practically impossible for that same theorist to attempt to speak on behalf of all of Christendom. Therefore, the most that any Protestant legal theory can hope for is to be confidently perspectival-confident in her reading of the Bible, confident in

I2 See, for example, Norman Doe's essay, "The Category 'Legal Theology' and the Study of Christian Laws," Journal of Law and Religion 32, no. I (2017) (this issue), for an extended discussion of how the various branches of academic theology might manifest themselves when used to answer foundational questions of law; see also, William S. Brewbaker, III's thought-provoking essay, "Creaturely Law," Journal of Law and Religion 32, no. I (2017) (this issue), on the theology of creation and the law. 
her broader reading and application of theology, while, at the same time, allowing for the perspectives from other Protestant theorists. Thus, there is not, nor can there be $a$ Protestant legal theory. There may be Reformed legal theories, Anglican legal theories, mainline legal theories, Restoration legal theories, and many others. This is the invitation, therefore, to let "a thousand flowers bloom," and to see multiple Protestant theories of law so that its readers may have a more multivalent perspective on the truth.

\section{Theonomy}

Yet another likely criticism of a Protestant legal theory is that is a thin front for a theonomic approach to law. Theonomy is an idea closely related to theocracy, and it holds that "God's law" should be established as the civil polity's law. For example, there are contemporary proponents who argue that the Deuteronomic/Levitical law found in the Old Testament should be established as America's civil law. Thus, a likely criticism is that Protestant legal theory is merely a ruse by which theonomists would import their own version of the law found in the Bible directly into the codebooks of America and its states.

Those critics, however, have little to be worried about since the purpose of Protestant legal theory (at least as this budding legal theorist conceives of it) is to criticize, provoke, conceptualize, and work alongside the existing structures, mechanisms, and content of the civil law. Though it will interact with many practical issues within the law, Protestant legal theory is first and foremost theoretical. Protestant legal theory is now, and always will be, a marginal approach to legal theory. Its cogency, persuasive appeal, and scholarly precision will determine how wide or narrow that margin will be. There is little to no chance of a theonomic coup of the government and its laws, because serious Protestant legal theorists do not want to take over. Protestant legal theory seeks to be more sophisticated, less sure of its itself, more amenable to theologizing rather than pronouncing certain theological statements, more reasonable, more academic, and most of all, more critical, than polemicists who wish to substitute biblical pronouncements of law for the society's civil law. Protestant legal theory is rooted in the rigor of academic theology and academic jurisprudence. It seeks to observe, argue, and persuade, from the confident perspective of its proponent's brand of Protestant theology, for incremental understanding and reform of the law to the end that decision by decision, statute by statute, regulation by regulation, those who make, implement, and obey law might exist together in evermore peaceful and just communities.

\section{Legal Theory Is Only Philosophical in Nature}

Even so, skeptics of a Protestant legal theory will surely contend that the project is doomed from its inception because, by definition, the fundamental questions of legal theory are purely philosophical, whose truth claims are determined solely by reason. Conversely, because the truth claims found within legal theory are inherently "reasonable" (in that they are grounded in reason), mixing theological "reasons" for those answers contaminates the search for the truth upon which all reasonable persons, can, nay, should agree. Further, because theologically oriented theorists cannot neutrally answer the most basic question - What is law? - the whole enterprise of theologically based theorizing is somehow suspect or illegitimate. ${ }^{\text {I3 }}$

I3 For criticism of a Rawlsian understanding of law based on the necessity of "public reasons," see Timothy P. Jackson's essay, “Theology and Law Divorced and Reconciled: Thomas, Luther, Rawls, and Us," Journal of Law and Religion 32, no. I (2017) (this issue). 
However, a theological approach to legal theory must be understood as one more method by which law may be understood. Philosophy and history are two other methods well known to legal scholars, and both philosophy and history have their own grammar, internal practices, and discipline-specific standards for what counts (and what does not) as good and acceptable philosophy and history. Moreover, it would be a rare (and puzzling) argument, indeed, if one were to argue that either philosophy or history were illegitimate interdisciplinary methods by which the scholar who deployed them could understand law. Yet, what is true of philosophy and history as methods is also true of theology. There are vocabularies and practices internal to theologians which help them better understand their discipline and their world. To foreclose theology as a method of understanding law, ab initio, because it is a discipline not accessible to everyone of reasonable goodwill, is to do so needlessly, without regard for the vistas of understanding that might result from theology's interaction with law.

\section{CONCLUSION}

It is clear that a fulsome Protestant legal theory will be built incrementally, and if it is a body of theory that is taken seriously, it will never be completely finished. That is both daunting and exciting. It is daunting because now is the time to begin the exacting and painstaking work of erecting the edifice that is the theory. It is exciting, because the vistas of possibility for the theory are as endless as God whom Protestant legal theorists serve. 